\section{A serviço da pátria: o recrutamento militar na Província do Paraná durante a Guerra do Paraguai (1865-1870)}

\author{
Edilson Pereira Brito \\ epebrito@gmail.com \\ Dissertação de Mestrado \\ Programa de Pós-Graduação em História \\ Universidade Federal de Santa Catarina
}

Florianópolis (SC) 2011

\section{In service of homeland: military recruitment in the Province of Paraná during the Paraguayan War (1865-1870)}

\author{
Edilson Pereira Brito \\ epebrito@gmail.com \\ Master Dissertation \\ Post-Graduate Program in History \\ Federal University of Santa Catarina \\ Florianópolis (Santa Catarina) - Brazil 2011
}

\begin{abstract}
O presente trabalho busca estudar o processo de recrutamento militar na Província do Paraná durante a Guerra do Paraguai. A pesquisa se baseou na análise de um grande corpus documental: notícias em periódicos relacionadas ao recrutamento e à guerra, ofícios enviados por particulares e por diversas autoridades locais ao presidente da Província, relatórios do presidente da Província apresentados à Assembleia Legislativa Provincial, relatórios do Ministério de Guerra e da Marinha, ofícios enviados pelo presidente da Província do Paraná ao Ministério do Império e da Guerra, obras literárias produzidas no período, relativas à guerra. $\bigcirc$ recorte temporal inicia-se no ano de 1865 e termina em 1870. O Paraná tornou-se foco de estudo por sua importância e especificidade diante do quadro geral brasileiro. Ao contrário das pesquisas realizadas por historiadores dedicados à história militar positivista, este estudo buscou acessar o universo das pessoas comuns. Neste sentido, centramos nossa análise na experiência de indígenas, homens pobres livres e libertos recrutados para o maior confronto sul-americano. Exatamente por isso, também se buscou analisar o recrutamento sob o prisma da história do trabalho, tendo em vista o fato do recrutamento e o posterior serviço no Exército ou na Armada serem associados ao trabalho forçado.
\end{abstract}

The research analyzes the military recruitment in the Province of Paraná, Brazil, for the Paraguayan War. It is based on a wide range of historical sources: news on recruitment and war, letters sent by local authorities and private individuals to the president of the Province, reports presented by the president to the Provincial Assembly, ministerial reports (Navy and War ministries), letters sent by the president of the Province of Paraná to the Ministry of Empire and of War, and literary works related to the war. It covers the period from 1865 to 1870 and focuses on Paraná because of the province's importance and specificity in Brazil. Unlike previous research on military history, this work highlighted the experience of common people. The chapters discuss the recruitment of free and poor men, freed persons and indigenous people for the most important South-American conflict. We consider recruitment through the perspective of labor history, since recruitment and service in the Army or Navy can often be associated to forced labor. 